\title{
A Preliminary Study on Primary Physical Educators' Attitudes toward Integrated Physical Education: Hong Kong Perspectives 主流小學體育教師融合體育教學態度初探：香港視角
}

\author{
LI Chunxiao CHEN Shihui TSOI Wing See Emily \\ Faculty of Arts and Sciences,
}

Hong Kong Institute of Education, HONG KONG

\section{李春曉陳適唓蔡钼思}

香港教育學院文理學院

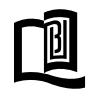

\begin{abstract}
The aim of the survey was to examine the attitudes of general primary PE teachers toward integrated PE and the relationships of gender, teaching experience, and class size. Eighty three teachers participated in the survey. The results indicated a neutral attitude towards integrated PE by teachers. There was a significant difference between male and female teachers in their perception of whether "students with disabilities like my teaching" $(p=0.018)$, but no significant differences with other attitudes by gender. There was a significant difference between teachers' teaching experiences and their perceptions of whether "Little support offered to integrated PE" $(\mathrm{p}=0.006)$, however, no significant differences with other items by experience. There was also a relationship between perceived teaching competency and class size $(\mathrm{p}<0.001, \mathrm{r}=0.454)$. The results were mainly discussed in relation to teaching competency, support, teaching experience and class size.
\end{abstract}

Keywords: physical educator, students with disabilities, integrated PE, attitudes

\section{摘 要}

本研究的目的在於探討香港主流小學體育教師融合體育教學態度。83位小學體育教師回應了本次調查。通過分析發現教師對 於融合體育教學持較為中立的態度。文章最後主要對融合體育態度與教學效能, 支援, 教學經驗和班級大小的關係维行了討論。

關鍵字: 體育教師, 特殊需要學生, 融合體育教學, 態度

\section{Introduction}

In the past decade, it has been witnessed that schools were experiencing a growing trend of integrating students with disabilities (SWD) into the general settings in different countries and areas. For example, approximately $95 \%$ of school-aged individuals with disabilities participate in general classes in U.S. (U.S. Department of Education, 2005). Hong Kong also took this action in terms of integrating SWD in the regular schools in late 1997 (Chen, Lau, \& Jin, 2006) and children with disabilities are currently served in three settings: (a) separated special school; (b) regular schools without integration; (c) regular schools with integration.

Most students with special education needs are educated in 60 special schools (EDB, 2007). Only some students with mild to moderate disabilities are included in regular schools in Hong Kong and students with learning disabilities, attention deficit disorder with hyperactivity, autism, speech impairment and mental retardation were commonly integrated (Li, Chen, \& Zhang, 2010). For those who integrated into the general primary schools, $93.0 \%$ of students with disabilities received physical 
education service and $71.0 \%$ of them accessed to integrated PE service delivery ( $\mathrm{Li}$ et al., 2010).

Teachers generally play a crucial role in promoting student learning in integrated settings (Liu, \& Silverman, 2006). Teachers' attitudes have been determined as a critical factor to successful integration in PE (Hutzler, 2003; Jarvis, \& French, 1990). Surveys that investigate the attitudes of teachers toward integration can be dated back to the 1970s (Hall, 1979; Lienert, Sherrill, \& Myers, 2001). In the 1980s, the survey instruments such as Physical Educators' Attitudes toward Teaching the Handicapped (PEATH) and Physical Educators' Attitude toward Teaching Individuals with Disabilities (PEATID) with reported reliabilities and validity were popularly applied for investigation of physical educators attitudes toward teaching SWD (Block, \& Obrusnikova, 2007).

Previous surveys regarding teachers' attitudes toward integration were focused on examining teacher-related variables to predict teachers' attitudes toward integration. These variables include perceived teaching competence and experience in teaching students with disabilities, academic preparation in special education or adapted physical education, age, and gender. Attitudes of physical educators in US are more likely to be favorable in teachers who have higher perceived teaching competence (Rizzo, \& Kirkendall, 1995; Rizzo, \& Vispoel, 1991).

Research has also shown that teachers with more experience with students with disabilities are more likely to have favorable attitudes to work with students with disabilities (Block, \& Obrusnikova, 2007). Other characteristics of physical educators such as gender and age have also been explored in previous studies; however, they indicated inconsistent findings (Rizzo \& Vispoel, 1991; Rizzo \& Wright, 1988). In addition, such variables as class size and support can directly influence teachers' teaching competence, and thus indirectly pose negative impact on teaching effectiveness. However, to our best knowledge, few studies were conducted to investigate the relationship between class size and teachers' attitudes within an integration environment.

Support provided for teachers within integrated physical education settings has been proven beneficial for both students with and without disability (Kasser, \& Lieberman, 2003; Block, \& Obrusnikova, 2007). Although not all children with disabilities require additional support, there is still unmet need for support in many schools and classes (Commonwealth of Australia, 2002). Some studies reported the lack of support rendered teachers with feelings of inadequacy and cannot meet demands for teaching integrated PE (Hardin, 2005; Hodge et al., 2004; Smith, \& Green, 2004).

In summary, teachers' attitudes toward integrated physical education are crucial for realizing integration. Teachers' attitudes toward integration have been examined in many countries or areas, such as in U.S. (e.g. Lieberman, Houston-Wilson, \& Kozub, 2002), German (e.g. Lienert, Sherrrill, \& Myers, 2001), and Taiwan (e.g. Shu, 1996). While Hong Kong has taken actions to included student with disabilities into regular settings for more than a decade, no study was ever conducted to address this issue in Hong Kong. Block and Obrusnikova (2007) indicated that research should examine the relationship between attitudes and background of the teachers such as gender and experience. In addition, there were limited studies investigating the relationship between class size and teachers attitudes related with teaching SWD. At present in Hong Kong, a class with less than 25 students can be defined as a small class size (EDB, 2007). Thus, this study was to address the following four research questions: (a) What were the teachers' attitudes toward integrated PE? (b) Can gender predict teachers' attitudes? (c) Was teaching experience a predictor to teachers' attitudes? (d) Are teachers' attitudes affected by class size?

\section{Method \\ Participants}

The target participants of this study were all $\mathrm{PE}$ teachers from the general primary schools in Hong Kong in which students with disabilities were included. According to the information from Education Bureau of Hong Kong (EDB), there were 280 general primary schools which integrated students with disabilities. Generally, there are at least two PE teachers from each primary school and they should possess education certificate in order to deliver PE service. Participants was a convenient sampling of PE teachers from these primary schools. Demographics of participants were presented in Table 1. The class sizes ranged from 8 to 36 (Mean $=$ 27.7). 


\section{Instrument revision}

This study used a cross-sectional design. In this survey, the integrated physical education was defined as when students with and without disabilities participate together during the physical education class (Place, \& Hodge, 2001). The definition of disability was cited from the Individuals with Disabilities Education Act (P.L. 10517).

Although there were some instruments popularly applied for investigation of physical educators attitudes toward teaching SWD (Block, \& Obrusnikova, 2007), they were not validated in Chinese population. Thus, the prototype of the instrument applied in this study was the Integrated Physical Education Service Delivery Questionnaire (IPESDQ) which was developed by Shu (1996) for his master thesis. The IPESDQ was a Chinese instrument created for obtaining preliminary information on basic issues related to integration as reported by general physical educators. The IPESDQ was then revised with reference to other instruments such as Teacher Integration Attitudes Questionnaire (TIAQ, Sideridis, \& Chandler, 1997) and other literature concerning integrated PE as to answer some specific research questions in this study (e.g. class size).

When the initial version of IPESDQ was revised, a panel of experts $(\mathrm{n}=8)$, including professors in special education and adapted PE, were invited to evaluate each item of the initial IPESDQ, and all suggestions were considered in further modifying the IPESDQ and the instrument was proved to have content-related evidence (Crocker, \& Algibam 1986). An additional review of the revised IPESDQ was conducted by 10 physical educators from general primary schools in Hong Kong. All suggestions were considered, and the IPESDQ can be deemed to have face validity following Borg and Gall's (1989) validation process. One week interval test and re-test reliability on 10 general primary PE teachers was .76 in this study.

The final version of the IPESDQ includes four parts and a total of 41 items. The first part is for understanding the personnel profile of participants (7 items from items 1 to 7). Part two is for examining the integrated PE service delivery (18 items from items 8 to 27). Part three is for studying the integrated PE service barriers (2 items from items 28-29). Part four is planned to investigate PE personnel needs (12 items from item 30 to 41 ).
Items other than the first part and nine scale items of the instrument were not reported in this manuscript as the authors already published an article by using these data. The nine scale items used for analyzed in this study are: I feel that (a) I feel competent teaching integrated PE; (b) SWD like my teaching; (c) SWD should be integrated into general settings; (d) government should issue policies or regulations for developing integrated PE; (e) government should hold more sports meetings for students with disabilities; (f) policy makers should offer curriculum guidance and teaching materials on integrated PE; (g) an integrated PE teacher should possess a certificate of Adapted PE; (h) little attention offered to integrated PE from my schools; and (i) it is necessary to provide financial resources for sports facilities and equipments. The participants used the five-point Likert scale $(1=$ strongly agree, $5=$ strongly disagree $)$ to express values on the above attitudes. Four items (i.e., "I feel competent teaching inclusive PE", "SWD like my teaching", "SWD should be integrated", and "Little support offered to integrated PE") were used for examining any significant difference by gender, teaching experience, and class size through analysis of variance (ANOVA) as they were the most important items based on the literature review in this study.

\section{Data collection}

Initially 115 teachers consented to participate in this survey. A questionnaire, a postage paid return envelope (not for participants using email) and a cover letter explaining the purpose of the study and instructions for completing the questionnaire were then delivered or emailed to each participant. Sixty additional questionnaires were collected after first mail-out. A follow-up was made to contact nonrespondents two weeks after the initial dissemination of questionnaires (Porretta, Kozub \& Lisboa, 2000). After the second round mail-out, another 23 questionnaires were collected. The total number of returned questionnaires was 83 (a 72.17\% response rate).

\section{Data analysis}

SPSS 17.0 for Windows were used to analyze the collected data. Descriptive statistics such as frequencies and percentage were used to report demographic data. Teachers' attitudes were calculated by means and standard deviations. ANOVA was then used for examining any significant difference in the relationship of four selected 
teachers' attitudes by gender, and teaching experience. Pearson's correlations were used for analyzing the relationships between teachers' attitudes and class sizes. Due to the limited sample size, only the novice (1-2 years) and experienced teacher groups ( $>6$ years) used for comparison of difference between teaching experience and four selected teachers' attitudes. Cohen's d was used for calculating effect size for items with significant statistical difference. According to Cohen (1988), a d value of 0.2 to 0.3 might be considered as a "small" effect, around 0.5 a "medium" effect and 0.8 to infinity, a "large" effect.

\section{Results}

Means and standard deviations of the score of all teachers' attitudes with integrated physical education are presented in Table 2. The teachers responded with a comparatively low score on items such as "SWD like my teaching" (1.97), "More sports meetings for SWD" (2.08), "Little attention offered to integrated PE" (2.13), and "Financial resources for sports facilities and equipment" (2.19). Scores on "SWD should be integrated" (2.25), "Offer curriculum guidance and teaching materials" (2.34), "Issue policies/ regulations for developing integrated PE" (2.35), and "Should possess a certificate of Adapted PE" (2.57) were neutral, while item on "I feel competent teaching" (2.81) received the highest score when compared with the score of other items. Overall, teachers were neutral with integrated $\mathrm{PE}$ in Hong Kong.

Table 3 presents the differences among the four selected teachers' attitudes by gender. There was a significant difference between "SWD like my teaching" and gender $(\mathrm{p}=0.018, \mathrm{~d}=-0.63)$, and male teachers were more likely to think students like their teaching. However, there was no gender difference in the three items, namely "SWD should be integrated", "SWD should be integrated" and "little support offered to integrated PE". Male teachers were more commonly shown to be favorable in items "SWD should be integrated" (2.16) than females (2.45). Female teachers however had a higher level of perceived teaching competence (2.73) and "feel little support offered to integrated PE" (1.92) than males (2.84 and 2.22).

Another description on teachers' attitudes and teaching experience is provided in Table 4. There was a significant difference between "Little support offered to integrated PE" and teaching experience $(\mathrm{p}=0.006$, $\mathrm{d}=-0.73$ ) and teachers with longer teaching experience showed more positive attitude (2.57) than novice teachers (2.00). However, experienced teachers presented higher scores on "I feel competent teaching" (3.18) and "SWD like my teaching" (2.11) than novice teachers (2.56 and 1.88). Further, both novice and experienced teachers were somewhat neutral on "SWD should be integrated" (2.25).

Big range of class sizes was observed, which ranged from 8 to 36 and most integrated classroom integrated 1-3 students with disabilities according to our findings. Table 5 demonstrated the correlations of four selected teachers' attitudes by class size. There was significant differences between "I feel competent teaching" and class size $(\mathrm{p}<0.001, \mathrm{r}=0.454)$. However, there were no significant difference between "SWD should be integrated" and class size $(\mathrm{p}=0.526)$, and "Little support offered to integrated PE" $(p=0.929)$ and class size $(p=0.106)$. The result also indicated that the larger the class size the less competent the teacher felt.

\section{Discussion}

This study aimed to examine the teachers' attitudes with integrated PE in Hong Kong. The findings generally revealed that teachers were somewhat neutral toward teaching students with disabilities in regular settings. The findings are discussed in terms of four aspects. The first aspect was related with teaching competency. Although teachers thought students like their teaching, they were not shown to have a high regard to themselves in terms of their own teaching competency. This may be due to the lack of academic preparation and practical experience in adapted physical education for some teachers (Block, \& Obrusnikova, 2007; Hardin, 2005; Li et al., 2010). The Hong Kong Institute of Education is a teacher training institution which is responsible for over 95\% of teaching training in Hong Kong, does not offer any Adapted PE degree program to train pre-service teachers to teach adapted PE in regular settings (Chen et al., 2006). A recent survey conducted by $\mathrm{Li}$ and his colleagues (2010) found that $44.0 \%$ of the PE teachers in Hong Kong have never received training on integrated PE and 83.1\% of them indicated a need to receive in-service training on Adapted PE. It is suggested that tertiary institutes in Hong Kong should consider ways to prepare these teachers for integrated PE instruction. 
Table 1. Demographic Characteristics of Participants ( $n=83$ ).

\begin{tabular}{lcc}
\hline Characteristics & $\mathrm{n}$ & $\%$ \\
\hline Gender & 52 & 62.7 \\
$\quad$ Male & 31 & 37.3 \\
$\quad$ Female & & \\
Age & 46 & 55.4 \\
$21-30$ & 25 & 30.2 \\
$31-40$ & 8 & 9.6 \\
$41-50$ & 4 & 4.8 \\
$>50$ & & \\
Teaching Experience (years) & 34 & 41.0 \\
$1-2$ & 20 & 24.1 \\
$3-5$ & 9 & 10.8 \\
$6-10$ & 20 & 24.1 \\
$>10$ & & \\
\hline
\end{tabular}

Table 2. Means and Standard Deviations of Teachers' Attitudes with Integrated Physical Education (n=83).

\begin{tabular}{lc}
\hline Attitudes & Mean (SD) \\
\hline I feel competent teaching & $2.81(0.812)$ \\
SWD like my teaching & $1.97(0.707)$ \\
SWD should be integrated & $2.25(0.830)$ \\
Little attention offered to integrated PE & $2.13(0.793)$ \\
Issue policies/regulations for developing integrated PE & $2.35(0.862)$ \\
More sports meetings for SWD & $2.08(0.736)$ \\
Offer curriculum guidance and teaching materials & $2.34(0.769)$ \\
Should possess a certificate of Adapted PE & $2.57(1.128)$ \\
Financial resources for sports facilities and equipments & $2.19(0.903)$ \\
\hline
\end{tabular}

Note. $(1$ = strongly agree, $5=$ strongly disagree $)$

Table 3. Means and Standard Deviations of Teachers' Attitudes with Integrated Physical Education by Gender.

\begin{tabular}{lccc}
\hline Attitudes & $\mathrm{M}(\mathrm{n}=52)$ & $\mathrm{F}(\mathrm{n}=31)$ & $\mathrm{p}$-Value \\
\cline { 2 - 3 } & $\mathrm{Mean}(\mathrm{SD})$ & $\mathrm{Mean}(\mathrm{SD})$ & \\
I feel competent teaching & $2.84(0.834)$ & $2.73(0.767)$ & 0.598 \\
SWD like my teaching & $1.85(0.705)$ & $2.27(0.631)$ & $0.018^{*}$ \\
SWD should be integrated & $2.16(0.877)$ & $2.45(0.671)$ & 0.166 \\
Little support offered to integrated PE & $2.22(0.789)$ & $1.92(0.776)$ & 0.114 \\
\hline
\end{tabular}

Note. ${ }^{*} \mathrm{p}<0.05$ 
Table 4. Means and Standard Deviations of Teachers' Attitudes with Integrated Physical Education by Teaching Experience.

\begin{tabular}{lccc}
\hline Attitudes & $1-2$ years & $>6$ years $)$ & \\
& & $(\mathrm{n}=32)$ & p-Value \\
\cline { 2 - 3 } & Mean $(\mathrm{SD})$ & Mean $(\mathrm{SD})$ & \\
& & & - \\
I feel competent teaching & $2.56(0.948)$ & $3.18(0.390)$ & 0.203 \\
SWD like my teaching & $1.88(0.793)$ & $2.11(0.567)$ & 1.000 \\
SWD should be integrated & $2.25(0.916)$ & $2.25(0.844)$ & $0.006^{*}$ \\
Little support offered to integrated PE & $2.00(0.778)$ & $2.57(0.790)$ & \\
\hline
\end{tabular}

Note. $-=$ Significance of the Test of Homogeneity of Variances was found

Table 5. Results of Correlations between Teachers' Attitudes and Class Size (n=83).

\begin{tabular}{|c|c|c|c|c|c|}
\hline & & $\begin{array}{c}\text { I feel competent } \\
\text { teaching }\end{array}$ & $\begin{array}{l}\text { SWD Like my } \\
\text { teaching }\end{array}$ & $\begin{array}{c}\text { SWD should be } \\
\text { integrated }\end{array}$ & $\begin{array}{l}\text { Little support offered } \\
\text { to integrated PE }\end{array}$ \\
\hline \multirow[t]{2}{*}{ Class Size } & $\begin{array}{l}\text { Pearson } \\
\text { Correlation }\end{array}$ & $.454^{* *}$ & .073 & -.010 & .186 \\
\hline & Sig. (2-tailed) & .000 & .526 & .929 & .106 \\
\hline
\end{tabular}

**. Correlation is significant at the 0.01 level (2-tailed). 
The result of this study showed that limited support or attention was paid to integrated $\mathrm{PE}$, which can pose negative impact on perceived teaching competency (Hardin, 2005; Hodge el al., 2004; Kasser, \& Lieberman, 2003). The item score of "SWD should be integrated" implied a weak agreement towards integrating students with disabilities into general classes in teachers. This score is expected since previous research findings indicated that perceived teaching competency is a strong predictor related to attitudes toward teaching students with disabilities (Rizzo, \& Kirkendall, 1995; Rizzo, \& Vispoel, 1991) so that it is reasonable to find a lower sense that SWD should be integrated.

The second aspect is that more support to integrated physical education service delivery should be provided for PE teachers. The rather low scores on items such as "Issue policies/regulations for developing integrated PE", "more sports meetings for SWD", "offer curriculum guidance and teaching materials", and "financial resources for sports facilities and equipments" of the results suggested teachers were in demand of these resources or support for developing integrated PE. This is consistent with the finding in a previous study conducted in Hong Kong (Li et al., 2010), teachers clearly indicated to the school administration or policy makers to adapt the environment of integration to suit the needs of both school and students (Fullan, 2001).

The third aspect is on predictors for attitudes with teaching SWD. Previous studies concluded that gender has less consistent relationships with attitudes (Hutzler, 2003). In this study, there was a significant difference between gender and "SWD like my teaching", and male teachers had more favorable attitude toward integrating students with disabilities than female colleagues. This conflicting result deserves further investigate. A significant difference was found between teaching experience and "Little support offered to integrated PE". Teachers with more experience in teaching claimed less needs or support on integrated PE, this finding follows the traditional image (Liu, \& Silverman, 2006). However, there was no significant difference between experience and "SWD like my teaching".

Teachers with more experience did not show a more positive attitude towards teaching students with disabilities. This result conflicts with the previous studies which proved favorable attitudes toward teaching students with severe disabilities were associated with quality of teaching experiences (Chandler \& Greene, 1995; Hodge et al., 2004; Lieberman, Houston-Wilson, \& Kozub, 2002). One explanation to this conflict is that teachers with long teaching experience in PE cannot guarantee they have long work experience with SWD.

The fourth aspect is that a smaller class size policy should be employed. A very recent research findings by Bruhwiler and Blatchford (in press) showed that there was a relationship between class size and teaching competency. In this study, there was a significant difference between "I feel competent teaching" and class size and there was a decrease level on perceived teaching competency as class size increase. That means smaller classes predict greater sense of competency concerning teaching students with disabilities in general settings. This is also consistent with previous research findings (Hodge et al., 2004). In this study, big range of class sizes was observed, which ranged from 8 to 36 and most integrated classroom integrated 1-3 students with disabilities. Sherrill (2004) recommended physical education class size should not be over 30; otherwise it may result in defeat, teacher burnout, and intensifying discipline problems. It was also recommended that each integrated classroom should integrate 1-2 students with disabilities. Thus, it is necessary to reduce the class size and the number of SWD integrated in general class in Hong Kong.

\section{Conclusions and Implications}

Findings of this study may expand our current understandings of teachers' attitudes on integrated PE. General primary physical educators in Hong Kong stood neutral positions toward teaching students with disabilities. Teachers' perceived competence with teaching integrated PE was unsatisfactory as the lack of support, curriculum guidance, and teacher preparation. Teachers have to develop their skills necessary for effective teaching, thus teachers' needs must be addressed. There is also a need for stakeholders to issue policies and regulations for integrated PE (e.g., curriculum guidance for integrated PE). Examination of attitudes by gender concluded a conflicting result compared with previous findings, and showed that male teachers had more favorable attitude towards integrating students with disabilities than females in Hong Kong. The contextual factors such as specific characteristics of Hong Kong physical educators can be attributed to the controversial findings. A significant 
difference between teaching experience and attitude on "Little support offered to integrated PE" was found, but teaching experience did not affect the attitude on "SWD like my teaching". The rationale behind that is worth further study. The big class size did pose negative impact on educators' perceived teaching competency. It is necessary to reduce the class sizes to less than 30 and to integrate not more than 2 students with disabilities in each class. The interpretation of results, however, should be cautious due to the small sample size in this study. Further studies of primary or secondary school teachers could provide more information through including a larger number of participants. It is also recommended that more studies should be conducted to examine the relationship between class size and attitudes of both teachers and students toward integrated PE. Further study may apply qualitative research approaches to explore attitudes of integration toward SWD as few studies have been conducted with these methods (Li, 2010).

\section{References}

Block, M. E., \& Obrusnikova, I. (2007). Inclusion in physical education: A review of the literature from 1995-2005. Adapted Physical Activity Quarterly, 24, 103-124.

Borg, W., \& Gall, M. (1989). Educational research: An introduction. New York, U.S.: Longman.

Bruhwiler, C., \& Blatchford, P. (in press). Effects of class size and adaptive teaching competency on classroom processes and academic outcome. Learning and Instruction, doi:10.1016/j.learninstruc.2009.11.004

Chandler, J. P., \& Greene, J. L. (1995). A statewide survey of adapted physical education service delivery and teacher in-service training. Adapted Physical Activity Quarterly, 12, 262-274

Chen, S., Lau, K., \& Jin, M. (2006). Students' attitudes toward including students with disabilities in regular PE settings in Hong Kong and TaiWan. Asian Journal of Exercise \& Sport Science, 3(1), 35-39.
Cohen, J. (1988). Statistical Power Analysis for the Behavioral Sciences (2nd ed.). Lawrence Erlbaum Associates.

Commonwealth of Australia. (2002). Education of students with disabilities. Canberra: Department of the Senate.

Conatser, P., Block, M., \& Lepor, M. (2000). Aquatic instructors' attitudes toward teaching students with disabilities. Adapted Physical Activity Quarterly, 17, 197-207.

Crocker, L., \& Algina, J. (1986). Introduction to classical and modern test theory. New York: Harcourt Brace Jovanovich College Publishers.

Cronbach, L., \& Algina, J. (1986). Introduction to classical and modern test theory. Orlando, FL: Harcourt Brace Jovanovich College Publishers.

EDB (2007). Inclusion. Retrieved from http://www.edb. gov.hk/index.aspx?nodeID=7400\&langno=2

Fullan, M. (2001). The new meaning of educational change (3rd ed.). New York: Teachers College Press.

Hall, G. E. (1979). The concerns-based approach to facilitating change. Educational Horizons, 57 (4), 202-208.

Hardin, B. (2005). Physical education teachers' reflections on preparation for inclusion. Physical Educator, 62(1), 44-56.

Hodge, S.R., Ammah, J.O., Casebolt, K.C., Lamaster, K., \& O'Sullivan, M. (2004). High school general physical education teachers' behaviors and beliefs associated with inclusion. Sport, Education and Society, 9(3), 395-419.

Hutzler, Y. (2003). Attitudes toward the participation of individuals with disabilities in physical activity: A review. Quest, 55, 347-373.

Individuals with Disabilities Education Act Amendments of 1997 (P.L. 105-17), 111 Stat. 37-157 (1997). 
Jarvis, C. K., \& French, R. (1990). Attitudes of physical educators toward the integration of handicapped students. Perceptual and Motor Skills, 70, 899-902.

Kasser, S. L., \& Lieberman, L. (2003). Maximizing learning opportunities through activity modification. Teaching Elementary Physical Education, 4(3), 19-22.

Li, C. (2010). Practice of inclusive physical education in primary schools in Hong Kong: teachers' perspectives. (Unpublished master's thesis). The Hong Kong Institute of Education, Hong Kong.

Li, C. Chen, S., \& Zhang, J. (2010). A status analysis of the integrated physical education in Hong Kong elementary schools. Asian Journal of Exercise \& Sports Science, 7, 1-7.

Lieberman, L. J., Houston-Wilson, C., \& Kozub, F. M. (2002). Perceived barriers to including students with visual impairments in general physical education. Adapted Physical Activity Quarterly, 19, 364-377.

Lienert. C., Sherrrill, C., \& Myers, B. (2001). Physical educators' concerns about integrating children with disabilities: A cross-cultural comparison. Adapted Physical Activity Quarterly, 18, 1-17.

Liu, H., \& Silverman, S. (2006). The value profile of physical education teachers in Taiwan, ROC. Sport, Education and Society, 11 (2), 173-191.

Place, K., \& Hodge, S. R. (2001). Social inclusion of students with physical disabilities in general physical education: A behavioral analysis. Adapted Physical Activity Quarterly, 18, 389-404.

Porretta, D., Kozub, F., \& Lisboa, F. (2000). Documentary analysis of survey research in adapted physical activity: 1984-1998. Adapted Physical Activity Quarterly, 17, 286-298.

Rizzo, T. L., \& Kirkendall, D. R. (1995). Teaching students with mild disabilities: What affects attitudes of future physical educators? Adapted Physical Activity Quarterly, 12(3), 205-216.
Rizzo, T. L., \& Wright, R. G. (1988). Selected attributes related to physical educators' attitudes toward teaching students with handicaps. Mental Retardation, 26, 307309.

Rizzo, T. L., \& Vispoel, W. P. (1991). Physical educators' attributes and attitudes toward teaching students with handicaps. Adapted Physical Activity Quarterly, 8, 411 .

Sherrill, C. (2004). Adapted physical activity, recreation, and sport: Crossdisciplinary and lifespan. New York: McGraw Hill.

Shu, D. (1996). Current status and opinions on special physical education in Taiwan junior high schools: A survey study. (Unpublished master's thesis). The National Taiwan Normal University, Taiwan.

Sideridis, G. D., \& Chandler, J. P. (1997). Assessment of teacher attitudes toward inclusion of students with disabilities: A confirmatory factor analysis. Adapted Physical Activity Quarterly, 14, 51-64.

Smith, A., \& Green, K. (2004). Including pupils with special educational needs in secondary school physical education: A sociological analysis of teachers' views. British Journal of Sociology of Education, 25, 593607.

U.S. Department of Education (2005). Twenty-Fifth annual report to congress on the implementation of the individuals with Disabilities Education Act. Retrieved from http://www.ed.gov/about/reports/annual/osep/2003/ index.html

\section{Correspondence}

\section{Chunxiao}

Graduate School, HKIEd,

10 Tai Po Lo Pin Road,

Tai Po, N.T., Hong Kong

Email: cxli@ied.edu.hk

通訊位址：

李春曉

香港, 新界, 大埔, 大埔露屏路 10 號,

香港教育學院, 研究生院

電子郵箱：cxli@ied.edu.hk 